\title{
Marking behaviour and census of Eurasian otters (Lutra lutra) in riverine habitats: what can scat abundances and non-invasive genetic sampling tell us about otter numbers?
}

\author{
Marcia Sittenthaler ${ }^{1,2}$ (D) Eva Maria Schöll ${ }^{1}$ (D) Christoph Leeb $^{2,3}$ (D) Elisabeth Haring $^{2,4}$ (D) \\ Rosemarie Parz-Gollner ${ }^{1}$ (D) - Klaus Hackländer ${ }^{1}$ (D)
}

Received: 6 June 2019 / Accepted: 7 February 2020 / Published online: 21 February 2020

(C) The Author(s) 2020

\begin{abstract}
Growing human-wildlife conflicts and legal conservation obligations increased the need for precise information on Eurasian otter (Lutra lutra) population parameters for species status assessment and wildlife management measures. Scat surveys have become the method of choice to monitor species distribution range, abundance and habitat use. Although methodological concerns exist, scat abundance is often used as main indicator for otter population estimates and trends. To evaluate whether scat counts serve as good proxy for otter densities in linear stream habitats, we modelled the relationship between old/fresh scat abundance and otter numbers on two spatial scales, including also seasonal effects. Actual otter densities and marking behaviour were ascertained by genotyping of otter faeces collected at 218 marking sites along $132.6 \mathrm{~km}$ of four salmonid streams. Otter densities in our study areas ranged from 0.16 to 0.28 otters per stream kilometre. The age of scats and the level of spatial scale were determining factors when evaluating the suitability of scat abundance as index for otter densities. Covering large parts of an otter's territory, fresh scat abundance increased with otter density, irrespectively of season. On the spatial scale of single marking sites, the relationship was not well supported, and no relationship could be found when using old scats in the models. Otter marking behaviour and differences in marking site use intensity, as well as seasonal differences in traceability and accumulation of old scats were discussed to bias the relationship between scat abundance and otter numbers.
\end{abstract}

Keywords Faeces $\cdot$ Genotyping $\cdot$ Salmonid streams $\cdot$ Scent marking $\cdot$ Scat count survey $\cdot$ Population density

Communicated by: Andrzej Zalewski

Electronic supplementary material The online version of this article (https://doi.org/10.1007/s13364-020-00486-y) contains supplementary material, which is available to authorized users.

Marcia Sittenthaler

marcia.sittenthaler@boku.ac.at; marcia.sittenthaler@nhmwien.ac.at

1 Department of Integrative Biology and Biodiversity Research, Institute of Wildlife Biology and Game Management, University of Natural Resources and Life Sciences, Vienna, Gregor-Mendel Strasse 33, 1180 Vienna, Austria

2 Central Research Laboratories, Natural History Museum Vienna, Burgring 7, 1010 Vienna, Austria

3 Institute for Environmental Sciences, University of Koblenz-Landau, Forststrasse 7, 76829 Landau, Germany

4 Department of Evolutionary Biology, University of Vienna, Althanstrasse 14, 1090 Vienna, Austria

\section{Introduction}

Unbiased estimators for distribution and abundance of animal species are fundamental to understand population ecology, necessary for legally required reporting obligations (e. g., according to the EU Habitats Directive 92/43/EEC), and critical to make sound wildlife management decisions (e. g., evaluation of the effectiveness of conservation measures or regulating plans). Data on these population parameters are particularly interesting for animal species that have suffered from persecution for a long period and by now are recovering due to increased conservation measures (Chapron et al. 2014; Ripple et al. 2014), and/or species which compete with humans for natural resources. However, direct observations and counting of animal numbers may be difficult, especially when elusive and nocturnal species with large home ranges are the object of interest, like it is the case with the Eurasian otter (Lutra lutra). Consequently, for such species indirect 
field census methods (e. g., counting tracks, faeces, latrines, territory marking sites, feeding traces and active dens) have been developed to estimate their distribution and their relative and absolute abundance (Wilson and Delahay 2001).

After the severe decline in the mid twentieth century observed in many European countries, otter populations have started to recover due to species protection and habitat conservation measures (Mason and MacDonald 1986; Roos et al. 2015). The population recovery has led to a revival of conflicts between the feeding needs of this fish-eating mustelid, commercial fisheries and anglers, and nature conservation proponents (Klenke et al. 2013). These human-wildlife conflicts and the conservation status of otters (Annex II and IV of the EU Habitats Directive) increased the need for accurate methods to get detailed knowledge on otter population parameters and status assessment. Otters are secretive, mostly nocturnal living animals, but deposit scats (so-called otter spraints) at conspicuous sites along the watercourse (Reuther et al. 2000; Kruuk 2006). Hence, scat count surveys have become a commonly used monitoring approach to ascertain otter distribution range (Reuther et al. 2000), habitat selection (Mason and MacDonald 1987; Ottino and Giller 2004; Romanowski et al. 2013), activity (Guter et al. 2008; Day et al. 2016; Rivera et al. 2019) and relative abundance (Jefferies 1986; Mason and Macdonald 1987; Strachan and Jefferies 1996). While scat surveys are an approved method to assess otter distribution (the so-called standard survey method according to Reuther et al. 2000), doubts and criticism have been raised on the validity and accuracy of this technique for conservation assessments (Reid et al. 2013) and to assess population density, as well as habitat utilisation (Kruuk et al. 1986; Kruuk and Conroy 1987). The concerns were mainly based on presumed individual differences in otter marking behaviour (Hutchings and White 2000; Kruuk 2006) as well as on seasonal and spatial differences in deposition and traceability of otter scats (Kruuk et al. 1986; Reuther et al. 2000). Although this methodological debate has never been solved and a standardised method how to extrapolate from scat abundances to otter densities is still missing, scat abundance is often used as a main indicator for otter population estimates and population trends (e. g., in national reports according to the Article 17 of the EU Habitats Directive). Hence, it is overdue to evaluate this methodological issue in estimating otter abundance or density.

During the last two decades, molecular genetic methods to identify individuals from non-invasively collected samples, gained increasing importance to study animal distribution, population sizes, as well as sex ratio, genetic variability and relatedness between individuals (Wilson and Delahay 2001; Schwartz et al. 2007; Marucco et al. 2011). Although noninvasive genetic monitoring has already become cheaper and less time consuming, it is still expensive compared to scat count surveys, and consequently, hardly applicable over extensive areas. Thus, if accurate estimates of absolute abundance (e. g., Kalz et al. 2006; Lampa et al. 2015b; Sittenthaler et al. 2015; Martin et al. 2017) are not feasible, scat count surveys will be the preferable method to assess population trends. However, for the use of scat counts as an index of animal abundance (at least for relative abundance), an indispensable prerequisite would be a strong relationship between abundances of scats and animals.

Kofler et al. (2018) modelled the relationship between scat abundance and otter numbers/densities in different otter habitats before estimating otter population size based on scat count surveys. Their models revealed a strong relationship between scat abundance and otter density in an area as well as between scat abundance and otter numbers at single marking sites. Other studies on different otter species (Lutra lutra: Ruiz-Olmo et al. 2001; Lanszki et al. 2008; Yoxon and Yoxon 2014; Lampa et al. 2015b, Lontra canadensis: Gallant et al. 2007; Mowry et al. 2011, and Lontra felina: Biffi and Williams 2017) used simple correlations between otter densities and scat abundance or marking sites to evaluate whether scat count surveys are a reliable tool for density assessment. Yet, those studies yielded conflicting results, which in some cases may be due to methodological issues and small sample sizes. Furthermore, knowledge on actual otter numbers in a study area would have been required, an information which is difficult to get.

To further expand our knowledge on upper reaches of streams in this study, we tested whether counting of scats (old and fresh) serves as a good proxy for otter densities in these habitats. We ascertained actual otter numbers by genotyping of otter scats collected at marking sites along the riverbanks of four salmonid streams. This data on actual otter densities and spatio-temporal distribution of individuals was used to investigate (1) if the number of otter individuals along a stream reflects scat abundance and how this relationship varies with season, age of the scats and spatial scale; and (2) how individual and/or sex-specific marking behaviour (individual scat deposition rates and frequencies of marking site use) is related to scat abundance. Outcomes of the study contribute to the improvement of survey techniques to monitor otter population trends.

\section{Material \& Methods}

\section{Study areas}

Otter scat collection took place at four salmonid streams of the upper Danube basin in northern and eastern parts of Austria (Province of Lower Austria): River Feistritz (F), River Ois (O), River Piesting (P) and River Ysper (Y) (Table 1). The study sites covered the most upper reaches of the streams including the main tributaries, which provided suitable 
habitats for otters. According to the longitudinal zonation of running waters (Illies 1961) and the ichthyological classification, all study sites belong to the epi- and metarhithral with salmonid species (Salmo trutta, Oncorhynchus mykiss, Thymallus thymallus) and bullhead (Cottus gobio) dominating the fish fauna.

For decades, otter populations had been close to extinction in Austria, but in the early 1990s, population recovery has started (reviewed by Jahrl 1999; Kranz et al. 2001; Sackl and Bauer 2001). Based on extensive mapping of otter signs in the years 2008 and 2018 in a region including our study areas (Kranz and Poledník 2009; Kofler et al. 2018), we assumed a stable, resident otter population for the time of our study in the study areas.

\section{Faecal sample collection}

Initially, we searched for typical otter marking sites along the watercourse, which were often located on sand banks, rocks, banks under bridges, otter trails and at tributary outfalls (Reuther et al. 2000; Kruuk 2006). Between July 2014 and July 2015, these marking sites were checked on a bimonthly basis for three consecutive days for otter scats, resulting in six collection periods per study site. On the first day of every collection period, we counted and removed old scats from each marking site and controlled every site repeatedly on the consecutive days to ensure a collection of fresh otter spraints deposited within the last $24 \mathrm{~h}$. As the age of the scat has already been identified as a crucial factor for DNA degradation and consequently genotyping success (Nsubuga et al. 2004; Hájková et al. 2006; Lampa et al. 2008), only these fresh scats were used for genotyping. Faecal samples were stored in a sample buffer (for details see Sittenthaler et al. 2015) until DNA extraction. According to the collection date, samples were assigned to meteorological seasons: spring (March-May) with six collection periods, summer (JuneAugust) with seven collection periods, autumn (SeptemberNovember) with five collection periods and winter (December-February) with six collection periods.

\section{Microsatellite genotyping and sex identification}

DNA extraction was carried out subsequently after every collection period, using the QIAamp DNA Stool Mini Kit (Qiagen, Germany) following the manufacturer's protocol and an elution of DNA with $100 \mu \mathrm{l}$ of AE Buffer. For identification of otter individuals faecal samples were genotyped at 11 (di- and tetranucleotide) microsatellite loci (Dallas and Piertney 1998): Lut435, Lut457, Lut615, Lut701, Lut717, Lut833 (multiplex set 1) and Lut453, Lut604, Lut715, Lut733, Lut832 (multiplex set 2), using an established protocol and PCR conditions (Sittenthaler et al. 2015). Fragment length analysis was performed on an ABI PRISM® 3130xl 
Sequence Analyzer (Applied Biosystems, USA). Alleles were analysed using automatic allele recognition and manually reviewed with GENEMAPPER 5.0 software (Applied Biosystems, USA).

Initially, all samples were amplified in independent quadruplicates for the first multiplex set to identify samples which failed to amplify in all of the six loci. These samples were considered as poor-quality samples and were excluded from further genotyping analyses. Subsequently, remaining samples were analysed with multiplex set 2 , and up to 8 additional PCR reactions for both sets were performed to determine a sample's consensus genotype (referring to the multiple tubes approach by Taberlet et al. 1996). A heterozygote genotype was accepted when each of both alleles was recorded at least twice and a homozygote genotype after at least three independent replications of a single allele. Samples that did not amplify at least at 10 loci were discarded. Sex identification was also performed in independent quadruplicates using an established protocol (Sittenthaler et al. 2015). Meeting the standards of working with non-invasive DNA samples, controls without template DNA were included throughout the extraction procedure and PCR amplifications to check for possible contaminations. Further, pre- and post-PCR pipetting was carried out in different laboratory rooms.

\section{Individual identification and relatedness}

To quantify the power of our microsatellite markers to differentiate between individuals, we calculated the probability of identity $\left(P_{I D}\right)$ and the probability of identity for siblings $\left(P_{I D s i b s}\right)$, which is a more conservative upper bound for the probability that two distinct individuals share the same genotype (Taberlet and Luikart 1999; Waits et al. 2001). For the computation of $P_{I D}$ and $P_{I D s i b s}$, as well as for checking matching pairs of genotyped samples and their assignment to otter individuals, we used the software GenAlEx 6.5 (Peakall and Smouse 2006, 2012). Due to an intensive sampling, consequently high recapture rates, and a conservative genotyping process, we aimed to minimise the risk of genotyping errors (especially ghost individuals due to allelic dropout; see Lampa et al. 2015a) in our data set. To further prevent the presence of ghost individuals in the data set, we reviewed the number and type (homozygous or heterozygous) of mismatching loci of each pair of individuals, especially for individuals recorded only one time. Although we had a dense network of repeatedly visited marking points within each study area (minimum of one marking site per stream kilometre) and achieved a high genotyping success rate, we could not assume that the number of unique genotypes corresponded to the actual number of otters in the areas. Hence, we estimated the number of otters in our study sites per collection period using the R-package capwire (Miller et al. 2005; Pennell et al. 2013), which applies a Likelihood ratio test to compare the goodness-of-fit of two computed models (equal capture model, two innate rate model). To further analyse the risk of systematically missing otter individuals due to seasonal differences in genotyping success rates, we conducted an ANOVA.

To identify possible siblings and parent-offspring relationships, we calculated the pairwise relatedness between individual otters using the software ML-RELATE (Kalinowski et al. 2006). Further, we tested possible parent-offspring combinations by the complete exclusion method based on Mendelian rules of inheritance (Jones et al. 2010) and verified relationship credibility by comparing temporal and spatial distribution of individual detections (see Sittenthaler et al. 2015).

Based on the number of recaptures per individual, spatiotemporal distribution, sex and relatedness between individuals, we classified individuals into following groups: (i) residents, (ii) offspring still accompanying the mother, and (iii) transient individuals.

\section{Modelling the relationship between scat abundance and otter densities}

To investigate the relationship between scat and otter abundance, we set up six different models. For the analyses we used two different levels of spatial scale: stream (model 1, 2, 3 and 4) and marking site (model 5 and 6 ) for a higher spatial resolution. Taking into account that otter scats were repeatedly collected at marking sites and streams throughout the whole study period, we applied Generalized Linear Mixed Models (GLMMs).

In our first two models (model 1 and 2), we fitted a GLMM with a Gamma distribution using a log link function with the number of old otter scats (for each study area and collection period: scats collected on the first day of a collection period per stream length divided by the number of marking sites per study area, $N=24$ ) as a function of otter density (model 1: number of otters recorded within a collection period divided by stream length; model 2: capwire population estimate divided by stream length). We used season as a second fixed covariate and included an interaction between both fixed-effect variables. Stream was included as a random variable.

In our third and fourth model (model 3 and 4), we also used a GLMM with a Gamma distribution using a log link function and set the number of fresh otter scats (for each study area and collection period: sum of scats collected on the second and third day of a collection period per stream length and divided by the number of marking sites, $N=24$ ) as response variable. All other fixed and random covariates and interaction terms stayed the same as in the first two models, whereas in model 3 for otter density we used again the number of otters recorded by genotyping and in model 4 for otter density we used the capwire population estimate. 
In our fifth and sixth model (models 5 and 6), we applied our data to a smaller spatial scale than in the first two models, where we counted scats and otters on stream level. Here, we modelled the absolute number of fresh scats on each positive marking site within a collection period as a function of covariates and fitted a Poisson GLMM with a log link function. Fixed covariates were the absolute number of otters detected at the specific marking site within a collection period, and season, and the interaction of the two covariates. To incorporate the dependency among repeated observations at marking sites grouped within streams, we included a nested random effect design (marking sites nested within streams). Due to a common genotyping success rate of otter scat samples of about 50\% (e. g., Hájková et al. 2009; Vergara et al. 2014; Sittenthaler et al. 2015), and the associated risk of false zeros or underestimation of otter individuals in the data, we included only marking sites with a genotyping success rate of $100 \%$, $N=162$ (model 5) and $\geq 50 \%, N=275$ (model 6).

Before fitting models, data exploration was carried out following a standard protocol (Zuur et al. 2010). The R-package lme4 (Bates et al. 2015) was used to generate a global model for each response variable including all parameters. To identify the most important variables, we applied a multimodel inference approach (Burnham and Anderson 2002; Burnham et al. 2011) using the R-package MuMIn (Bartón 2018). For a set of models representing all possible combinations of variables, we calculated the Akaike Information Criterion with a correction for small sample sizes $\left(\mathrm{AIC}_{\mathrm{c}}\right)$ (Hurvich and Tsai 1989), and finally selected those models with a $\Delta \mathrm{AIC}_{\mathrm{c}}<7$ (Burnham et al. 2011). Based on this subset of models, we calculated model-averaged coefficients. Conditional averaging was used because $\mathrm{AIC}_{\mathrm{c}}$ weights of best models were relatively high (see Table 2) (Grueber et al. 2011; Symonds and
Moussalli 2011). Relative importance values, as well as upper and lower bounds of the $95 \%$ confidence intervals (CI), were calculated for each parameter of the final model. Model parameters that did not include zero within their CI were considered as informative (Grueber et al. 2011). To describe the amount of variance explained, we calculated marginal and conditional $R^{2}$ for GLMMs as suggested by Nakagawa and Schielzeth (2013).

All statistical analyses were performed in an $\mathrm{R}$ environment (R 3.5.1, R Core Team 2018).

\section{Otter marking behaviour}

We used Kruskal-Wallis tests with a post-hoc DunnBonferroni test to investigate differences in detection rate and length of detection period (in days) between otter status categories (resident otters, cubs still accompanying their mothers and transient individuals) over the whole study period.

We tested for differences in spraint deposition rate between males and females and pooled the number of successfully genotyped faeces of each individual per night, collection period and over the whole study period. We conducted a MannWhitney-U test with a $p$ value correction according to Bonferroni-Holm to account for multiple testing.

Using a smaller spatial scale (marking site), we grouped data by marking site and analysed, how many different otters used a specific marking site within one night, one collection period and during the whole study period. Further, we analysed how often and how many scats one specific individual deposited at a specific marking site within a single night and again, tested for differences between sexes with a $G$-Test.

Table 2 Subsets of generalized linear mixed effect models $\left(\Delta \mathrm{AIC}_{\mathrm{c}}<7\right)$ explaining the abundance of otter scats at four salmonid streams in Austria based on a multimodel inference approach. $R^{2}{ }_{\operatorname{GLMM}(m)}=$

marginal $R^{2}$; amount of variance explained by fixed factors; $R_{\text {GLMM(c) }}^{2}=$ conditional $R^{2}$; amount of variance explained by the entire model including random factors

\begin{tabular}{|c|c|c|c|c|c|c|c|}
\hline Model & Response & Model subsets & $\mathrm{AIC}_{\mathrm{c}}$ & $\Delta \mathrm{AIC}_{\mathrm{c}}$ & $\mathrm{AIC}_{\mathrm{c}}$ weight & $R_{\mathrm{GLMM}(m)}^{2}$ & $R_{\mathrm{GLMM}(c)}^{2}$ \\
\hline 1 & Number of old scats per stream & $\begin{array}{l}=\beta_{0}+\text { season } \\
=\beta_{0}+\text { otter density } \\
=\beta_{0}+\text { otter density }+ \text { season } \\
=\beta_{0}\end{array}$ & $\begin{array}{l}-114.6 \\
-113.0 \\
-112.0 \\
-109.8\end{array}$ & $\begin{array}{l}0.00 \\
1.61 \\
2.62 \\
4.78\end{array}$ & $\begin{array}{l}0.553 \\
0.247 \\
0.149 \\
0.051\end{array}$ & $\begin{array}{l}0.445 \\
0.229 \\
0.508 \\
-\end{array}$ & $\begin{array}{l}0.502 \\
0.229 \\
0.508 \\
0.075\end{array}$ \\
\hline 2 & Number of old scats per stream & $\begin{array}{l}=\beta_{0}+\text { season } \\
=\beta_{0}+\text { estimated otter density } \\
=\beta_{0}+\text { estimated otter density }+ \text { season } \\
=\beta_{0}\end{array}$ & $\begin{array}{l}-114.6 \\
-111.8 \\
-111.0 \\
-109.8\end{array}$ & $\begin{array}{l}0.00 \\
2.79 \\
3.63 \\
4.78\end{array}$ & $\begin{array}{l}0.666 \\
0.165 \\
0.109 \\
0.061\end{array}$ & $\begin{array}{l}0.445 \\
0.192 \\
0.472 \\
-\end{array}$ & $\begin{array}{l}0.502 \\
0.192 \\
0.493 \\
0.075\end{array}$ \\
\hline 3 & Number of fresh scats per stream & $=\beta_{0}+$ otter density & -148.5 & 0.00 & 0.987 & 0.467 & 0.627 \\
\hline 4 & Number of fresh scats per stream & $\begin{array}{l}=\beta_{0}+\text { estimated otter density } \\
=\beta_{0}\end{array}$ & $\begin{array}{l}-142.2 \\
-138.2\end{array}$ & $\begin{array}{l}0.00 \\
4.04\end{array}$ & $\begin{array}{l}0.987 \\
0.117\end{array}$ & 0.467 & $\begin{array}{l}0.627 \\
0.179\end{array}$ \\
\hline 5 & $\begin{array}{l}\text { Number of fresh scats per marking } \\
\text { site with } 100 \% \text { genotyping success }\end{array}$ & $\begin{array}{l}=\beta_{0}+\text { number of otters } \\
=\beta_{0}+\text { number of otters }+ \text { season }\end{array}$ & $\begin{array}{l}411.6 \\
417.8\end{array}$ & $\begin{array}{l}0.00 \\
6.17\end{array}$ & $\begin{array}{l}0.955 \\
0.044\end{array}$ & $\begin{array}{l}0.075 \\
0.076\end{array}$ & $\begin{array}{l}0.075 \\
0.076\end{array}$ \\
\hline 6 & $\begin{array}{l}\text { Number of fresh scats per marking } \\
\text { site with } \geq 50 \% \text { genotyping success }\end{array}$ & $\begin{array}{l}=\beta_{0}+\text { number of otters } \\
=\beta_{0}+\text { number of otters }+ \text { season }\end{array}$ & $\begin{array}{l}904.7 \\
910.3\end{array}$ & $\begin{array}{l}0.00 \\
5.63\end{array}$ & $\begin{array}{l}0.940 \\
0.056\end{array}$ & $\begin{array}{l}0.187 \\
0.188\end{array}$ & $\begin{array}{l}0.190 \\
0.192\end{array}$ \\
\hline
\end{tabular}




\section{Results}

\section{Sample quality, individual identification and otter densities}

Overall, we collected 1872 old otter scat samples on day 1 of each collection period. Furthermore, for genetic analysis, 1039 fresh scats were collected on days 2 and 3 of each collection period, of which 592 revealed an unambiguous genotype resulting in 45 unique genotypes (Table 1; for individual detection rates see Table S1 in Online Resource 1). Hence, genotyping success rate per study area ranged between 50 and $64 \%$, leading to an average rate of $57 \%$. There was no difference in genotyping success between seasons (ANOVA, $F_{(3,20)}=0.066, p=0.977$ ). With a $P_{I D}$ of $1.1 \times 10^{-8}$ (eleven loci) and $4.2 \times 10^{-7}$ (nine loci), and a $P_{I D s i b s}$ of $3.5 \times 10^{-4}$ (eleven loci) and $1.7 \times 10^{-3}$ (nine loci), our set of microsatellites was adequate to differentiate even between closely related otter individuals within our study areas. All but three of our genotypes were represented by at least two independent samples (Table S1 Online Resource 1). As those genotypes differed in at least 4 loci ( 2 heterozygous loci) from other individuals, it was unlikely that these genotypes represented ghost individuals.

In a single collection period, density of resident adult otters at a stream varied between 0.07 and 0.21 individuals per stream kilometre. Taking also transient individuals and cubs into account, the density increased to 0.08 and 0.38 individuals per stream kilometre. Otter densities estimated with capwire taking potentially missed individuals into account ranged between 0.13 and 0.49 otter per stream kilometre (including transient otters and cubs).

\section{Relationship between scat abundance and otter densities}

For modelling abundance of old otter scats (model 1 and model 2), the subset of models with a $\Delta \mathrm{AIC}_{\mathrm{c}}<7$ consisted of four models (Table 2). The final averaged model included the variables season and otter density, but confidence intervals for the parameter estimates of otter density included zero and an importance value $<0.5$ indicated little evidence that this predictor affected abundance of old otter scats (Table 3). With an importance value of 0.7 and 0.77 , respectively, season had a significant effect on scat abundance. More specifically, we found lower scat abundance in summer compared to all other seasons (Fig. 1a, Table 3). The variance explained $\left(R_{\mathrm{GLMM}(m)}^{2}, R_{\mathrm{GLMM}(c)}^{2}\right)$ was similar, regardless if otter density was included in the model or not (Table 2).

The subset of models explaining variation in fresh otter scat abundance comprised one (model 3), or two (model 4) models, including otter density as only fixed factor (Table 2). Fresh otter scat abundance increased significantly with increasing otter densities, while the variable season had no effect on fresh scat abundance (Table 3, Fig. 1b).

For modelling number of fresh scats per marking site (models 5 and 6), the multimodel inference approach revealed a model subset consisting of two models (see Table 2). For both data sets (marking sites with $100 \%$ genotyping success only; marking sites with $\geq 50 \%$ genotyping success), the variables number of otters and season were included in the final model. The confidence intervals for the parameter estimates of season included zero and importance values of 0.04 and 0.06 , respectively, providing little evidence that this predictor affected number of fresh scats per marking site (Table 3). With increasing otter numbers, the number of fresh scats per marking site increased slightly. However, with a $R^{2}{ }_{\mathrm{GLMM}(m)}$ between 0.075 and 0.188 and a $R^{2}{ }_{\text {GLMM(c) }}$ between 0.075 and 0.192 not much variance was explained by the final models.

\section{Otter marking behaviour}

Generally, individual otters were recorded by several genotyped scats: over the whole study period up to 47 spraints originated from one individual, while within one collection period individuals were recorded by up to 17 spraints each and up to 13 spraints within one collection night. On average, single individuals were detected by 2.4 scats per night. Significant differences in detection, and hence, scat deposition rates between resident otters, cubs still accompanying their mothers, and transient individuals could be observed for the whole study period (Chi-Square $=13.605, d f=2, p=0.001$ ). On average resident otters had a 4.8-times higher detection rate compared with transient animals $(z=3.534, p<0.001)$ and 1.8-times higher than cubs $(z=-2.183, p=0.014)$. Concerning the number of days between the first and last detection of an individual (length of detection period), we found significant differences between all pairwise comparisons (Chi-Square $=23.456, d f=2, p<0.001)$, with resident individuals being detectable for the longest time, followed by cubs which still accompany their mothers. Transient individuals were detectable for short periods only. Nevertheless, variation in detection rate and length of detection period was variable within and between groups (Table 4).

Testing for sex differences in scat deposition rate revealed that males and females defecate at similar rates, irrespectively of time scale (collection night: $W=6956, p=0.268, N=255$; collection period: $W=3146, p=0.884, N=162$; whole study period: $W=334, p=0.129, N=45$ ).

Up to three otters deposited a scat at a specific marking site within one collection night and collection period, while up to six different individuals used the same marking site within a 12 months study period (see Fig. 2). However, these maxima were relatively scarce with only $1.2,3.3$ and $0.6 \%$, respectively, of all cases when data were grouped by marking site. Over the whole study period in $68.8 \%$ of all cases more than one otter 
Table 3 Model-averaged summary statistics of generalized linear mixed effect models explaining the abundance of otter scats at four salmonid streams in Austria: estimates of coefficients and standard error
(SE), lower and upper limits of the 95\% confidence intervals (CI 95\%) and relative importance values of the model parameters. Model averaging was applied to models with a $\Delta \mathrm{AIC}_{\mathrm{c}}<7$

\begin{tabular}{|c|c|c|c|c|c|c|}
\hline Model & Response & Variables & Estimate & SE & CI $95 \%$ & Relative Importance \\
\hline \multirow[t]{6}{*}{1} & \multirow[t]{6}{*}{ Number of old scats per stream } & Intercept & -3.642 & 0.245 & $-4.143 ;-3.140$ & \multirow{6}{*}{0.70} \\
\hline & & Season & & & & \\
\hline & & autumn & 0.523 & 0.217 & $0.069 ; 0.977$ & \\
\hline & & spring & 0.463 & 0.195 & $0.053 ; 0.872$ & \\
\hline & & winter & 0.831 & 0.206 & $0.399 ; 1.262$ & \\
\hline & & Otter density & 2.554 & 1.245 & $-0.015 ; 5.124$ & \\
\hline \multirow[t]{6}{*}{2} & \multirow[t]{6}{*}{ Number of old scats per stream } & Intercept & -3.575 & 0.218 & $-4.022 ;-3.128$ & \multirow{6}{*}{0.77} \\
\hline & & Season & & & & \\
\hline & & autumn & 0.543 & 0.215 & $0.091 ; 0.994$ & \\
\hline & & spring & 0.467 & 0.195 & $0.058 ; 0.877$ & \\
\hline & & winter & 0.846 & 0.202 & $0.422 ; 1.271$ & \\
\hline & & Estimated otter density & 1.519 & 1.161 & $-0.876 ; 3.914$ & \\
\hline \multirow[t]{2}{*}{3} & \multirow[t]{2}{*}{ Number of fresh scats per stream } & Intercept & -4.683 & 0.315 & $-5.300 ;-4.066$ & 0.27 \\
\hline & & Otter density & 4.867 & 1.161 & $2.593 ; 7.142$ & \multirow[t]{2}{*}{1.00} \\
\hline \multirow[t]{2}{*}{4} & \multirow[t]{2}{*}{ Number of fresh scats per stream } & Intercept & -4.226 & 0.344 & $-4.930 ;-3.522$ & \\
\hline & & Estimated otter density & 2.692 & 0.962 & $0.685 ; 4.700$ & \multirow[t]{2}{*}{0.88} \\
\hline \multirow[t]{6}{*}{5} & \multirow{6}{*}{$\begin{array}{l}\text { Number of fresh scats per marking } \\
\text { site with } 100 \% \text { genotyping success }\end{array}$} & Intercept & -0.339 & 0.167 & $-0.669 ;-0.010$ & \\
\hline & & Number of otters & 0.578 & 0.109 & $0.362 ; 0.794$ & \multirow{5}{*}{$\begin{array}{l}1.00 \\
0.04\end{array}$} \\
\hline & & Season & & & & \\
\hline & & autumn & 0.082 & 0.178 & $-0.269 ; 0.434$ & \\
\hline & & spring & -0.009 & 0.185 & $-0.375 ; 0.357$ & \\
\hline & & winter & 0.004 & 0.170 & $-0.333 ; 0.341$ & \\
\hline \multirow[t]{6}{*}{6} & \multirow{6}{*}{$\begin{array}{l}\text { Number of fresh scats per marking } \\
\text { site with } \geq 50 \% \text { genotyping success }\end{array}$} & Intercept & -0.062 & 0.102 & $-0.262 ; 0.138$ & \multirow{6}{*}{$\begin{array}{l}1.00 \\
0.06\end{array}$} \\
\hline & & Number of otters & 0.642 & 0.058 & $0.528 ; 0.756$ & \\
\hline & & Season & & & & \\
\hline & & autumn & -0.012 & 0.115 & $-0.239 ; 0.214$ & \\
\hline & & spring & -0.007 & 0.114 & $-0.231 ; 0.217$ & \\
\hline & & winter & 0.062 & 0.105 & $-0.144 ; 0.268$ & \\
\hline
\end{tabular}

used a specific marking site. However, at a smaller time scale (collection period or night), in the majority of all cases only one otter was recorded at a specific marking site (74.9 and 86.0\%).

The number of scats one specific otter deposited at a marking site varied from 1 to 6 within one night. In $15.4 \%$ of all cases, one individual left more than one spraint within one night at a specific marking site. Again, we did not find differences between male and female otters $(G=3.551, p=0.616)$.

\section{Discussion}

We analysed marking behaviour and densities of otters in salmonid streams using non-invasive genetic monitoring methods and investigated whether scat counts can be used as a reliable measure for quantifying otter numbers and consequently, population trends. In our four study areas, we found indications that under certain conditions the density of otters can represent the number of faecal samples along temperate salmonid streams. For this evaluation, we needed accurate information on otter numbers in our study areas, which we obtained by genotyping otter scats. However, faecal samples are commonly known to be prone to low DNA concentration and poor DNA quality, potentially leading to genotyping errors and low genotyping success rates (reviewed by Beja-Pereira et al. 2009). Other studies applying non-invasive genetic methods on otter scats obtained success rates between 14 and $73 \%$, i. e. on average $46 \%$ (e. g. Lanszki et al. 2008; Janssens et al. 2008; Hájková et al. 2009; Bonesi et al. 2013; Vergara et al. 2014; Lerone et al. 2014; Sittenthaler et al. 2015; Martin et al. 2017). The combination of a comparable high-average genotyping success rate of $57 \%$ and an extensive sampling scheme allowed us to draw reliable conclusions regarding otter densities in our study areas. We further confirmed otter densities based on genotyped otter scats using a population size estimator based on genetic capture-mark-recapture data. 


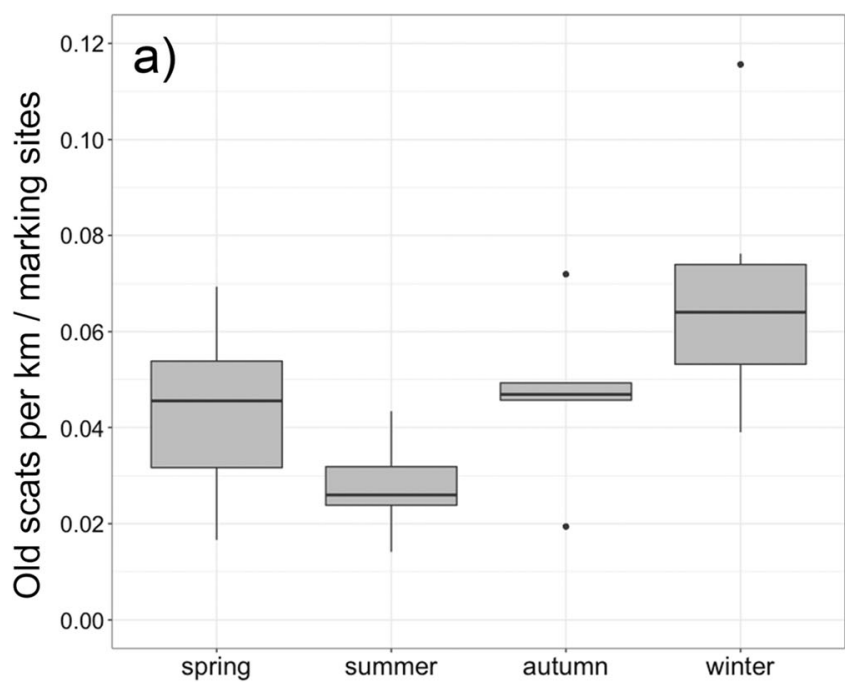

Fig. 1 Seasonal differences in otter scat abundance collected along salmonid streams in Austria: (a) old scats of the first day of a collection period per stream kilometre and number of marking sites per study area,

With mean otter densities ranging from 0.16 to 0.28 otters per stream kilometre (including all otters regardless of their status), and mean densities of estimated otters per stream kilometre ranging from 0.17 to 0.34 , our results are in line with other studies investigating otter densities in riverine habitats, where otter populations have either never been extinct, or have already re-established a self-sustaining population (Lanszki et al. 2008: 0.17 otters $/ \mathrm{km}$; Hájková et al. 2009: $0.22-0.26$ otters $/ \mathrm{km}$; Ruiz-Olmo et al. 2011: $0.07-0.26$ otters $/ \mathrm{km})$.

Concerning the suitability of scat abundance as an index for otter densities (as detected by our genotyping and population estimates), our results indicated three determining factors: the level of spatial scale; the age of the scats, which are used in scat surveys; and the time of year a scat survey is conducted.

On a lower spatial resolution covering large parts of an otter's home range (in temperate stream habitats: $>10-20$ stream kilometres; Weinberger et al. 2016) and using old scats only, no relationship between scat abundance and otter densities could be found. However, seasonal effects seemed to play a role in the abundance of old scats. The picture changed when using fresh scats: fresh scat abundance increased significantly

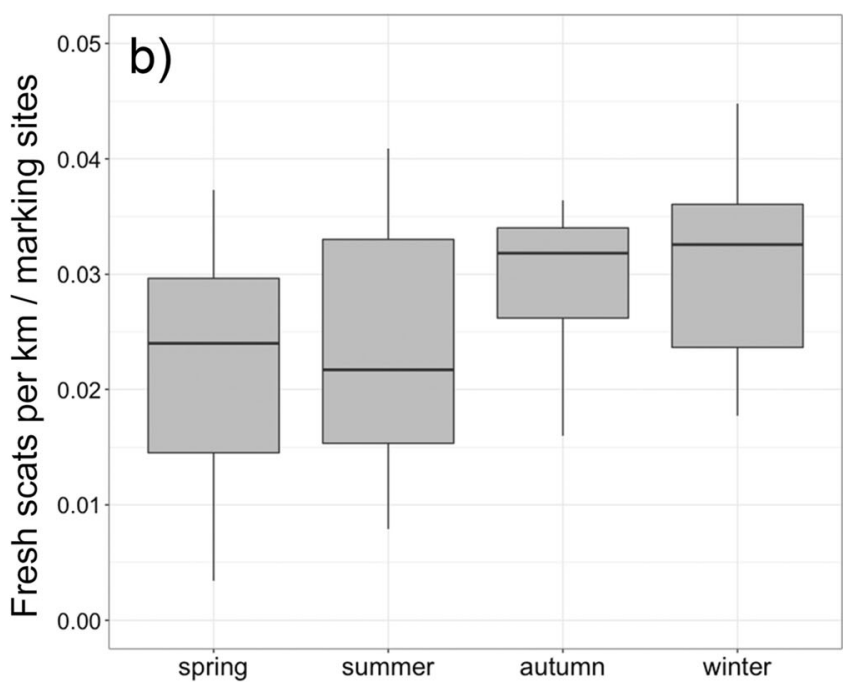

(b) fresh scats of the second and third day of a collection period per stream kilometre and number of marking sites per study area. The yaxis displays different scales for (a) and (b)

with otter densities, regardless of season. Analysing fresh scat abundance and otter numbers in more detail on a smaller spatial scale (i. e., single marking sites), there was a very weak relationship between otter numbers and fresh scats, regardless of season and genotyping success threshold used.

To evaluate the different outcomes of our models, we have to relate and discuss those factors, which determine how often and where the animal deposits a scat and secondly, factors, which determine the frequency and amount of scats being detected by a surveyor.

Scent profiles of otter scats showed that otters do not defecate for metabolism reasons only, as their scent signals sex, age and reproductive status, and even individual identity (Kean et al. 2011, 2015). Consequently, scent-marking serves as a communication tool in otters and other mustelids (Hutchings and White 2000; Kruuk 2006). Hence, marking behaviour might vary between individual otters. In contrast to the long-time assumption that females leave fewer scats at marking sites than males (based on a study by Green et al. (1984) on three radio-isotope labelled individuals), our results revealed that there was no difference in marking intensity between male and female otters. These results are in line with
Table 4 Number of detections and detection period length in days (mean $\pm \mathrm{SD}$ ) per individual for resident otters, cubs accompanying their mothers, transient otters, males and females in four Austrian salmonid streams between 2014 and 2015

\begin{tabular}{lllllll}
\hline \multirow{2}{*}{ Otters } & $\mathrm{N}$ & \multicolumn{2}{l}{ Number of detections } & \multirow{2}{*}{ Detection period [days] } \\
\cline { 3 - 5 } & & Min & Max & Median & Mean $\pm \mathrm{SD}$ & \\
\hline Residents & 22 & 2 & 47 & 13.5 & $18.73 \pm 14.17$ & $281 \pm 75$ \\
Offspring & 14 & 1 & 44 & 5.5 & $10.36 \pm 12.18$ & $150 \pm 120$ \\
Transients & 9 & 1 & 12 & 3 & $3.89 \pm 3.55$ & $36 \pm 33$ \\
Males & 22 & 1 & 40 & 6 & $10.59 \pm 11.96$ & $139 \pm 130$ \\
Females & 23 & 1 & 47 & 10 & $15.61 \pm 14.34$ & $241 \pm 108$ \\
Overall & 45 & 1 & 47 & 7 & $13.16 \pm 13.33$ & $191 \pm 129$ \\
\hline
\end{tabular}


(a)

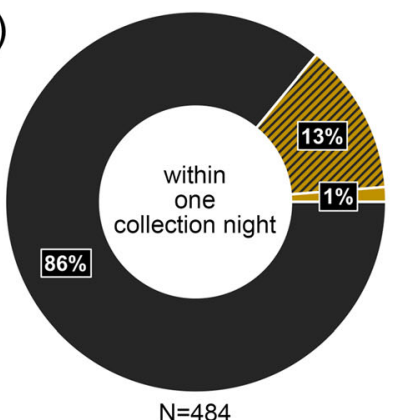

No. of

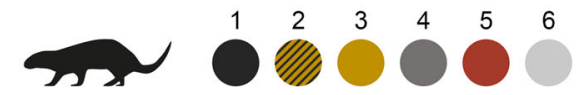

(b)

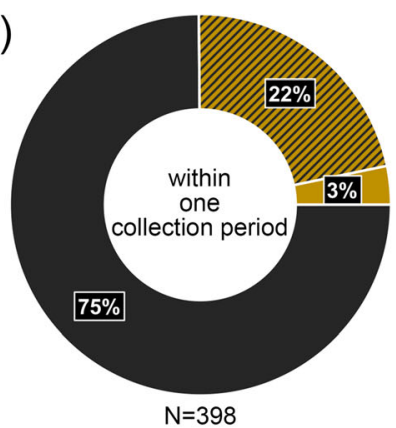

(c)

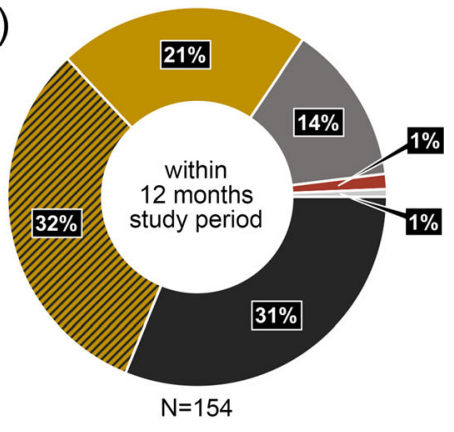

Fig. 2 Relative frequency of otter numbers using a specific marking site along salmonid streams in Austria (a) within one collection night, (b) within one collection period, and (c) during the whole study period covering 12 months

other studies, which also did not detect differences in deposition rates of scats between sexes (Kruuk 1992; Lampa et al. 2015b). Nevertheless, Lampa et al. (2015b) found higher deposition rates of anal gland secretions (so-called jellies) for males.

In our study areas, individual otters deposited scats repetitively at the same marking sites (even during one night), and up to three different otters used a specific marking site within one night, and even up to six otters used the same marking site within one year. Moreover, adult resident otters left spraints more often at marking sites than cubs or transient individuals did. These observed marking behaviour may be explained by the fact that otters and other mustelids often aggregate their scent marks close to the boundaries of their territories and/or signal important key resources within their territories by leaving scats at such specific sites (Kruuk 1992; Hutchings and White 2000; Remonti et al. 2011). In addition, marking behaviour and consequently the number of spraints at a site might also be biased by the amount of food resources available: sprainting activity increases significantly in areas with higher fish biomass availability (Hutchings and White 2000; White et al. 2003; Almeida et al. 2012). Consequently, single marking sites where otters deposit scats regularly may fulfil specific communication functions within an otter's territory. We found a weak indication for the relationship between otter numbers and scat counts on a local scale (i. e., marking site), but we could not explain much variation in otter scat abundance. This might be presumably due to otter marking behaviour in relation to resource availability and missing habitat information (e. g., fish biomass) in our modelling approach. Interestingly, in contrast to our findings Kofler et al. (2018) showed a strong relationship between scat abundance and otter individuals at the spatial level of single marking points. In their study they did not only include upper reaches of streams (like we did), but also middle and lower reaches, as well as fish ponds. The different habitats vary in resource availability conditions and hence, can influence the social structure and marking behaviour of otters in different habitats, which may be the reason why they obtained different results on a small scale level. As already stated by Kruuk et al. (1986), if scats are used as an indicator for otter densities and population trends, a large number of marking sites within a catchment area should be included to be able to cover a representative proportion of an otter's home range. A few randomly chosen marking sites may bias the results. RuizOlmo et al. (2001) concluded that otter scats provide only a rough picture of otter abundance. Although they found an increase of scats with increasing otter numbers, their results indicated a rapid saturation without a linear relationship (so did Kofler et al. 2018). The authors conceded that their survey stretches of 10 stream kilometres may have been too short and longer stretches may have given more accurate results.

Further, also seasonal fluctuations in marking behaviour of otters should be taken into account (Kruuk et al. 1986). When using old scats only, we found a significant seasonal effect on scat abundance. But, as frequency of fresh scats did not vary with season, a seasonal pattern of sprainting intensity induced by otters is not supported by our data. Hence, our results indicated that seasonal differences might be more related to traceability due to changes in vegetation cover throughout a year, water-level variations and weather conditions. On the other hand, at sheltered places otter scats also can remain unaffected for quite a long time (from several weeks up to one year) in the environment (Reuther et al. 2000), and spraints may accumulate at such sites. Similar to other studies investigating seasonality of sprainting behaviour in otters (Macdonald and Mason 1987; Reuther et al. 2000; Yoxon and Yoxon 2014), we found significant lower abundance of old scats in summer compared to all other seasons. The low abundance in summer may be explained either by flooding events caused by snow melting in spring, high precipitation or by difficulties in finding faecal samples due to high vegetation (e.g., reed, shrubs and bushes along the shore or river bank). Moreover, in summer there might be a higher decay rate of faeces in the field because the heat simply desiccates faeces more quickly, and at the same time there is a higher 
insect and bacteria activity compared to colder periods. Our findings are supported by Yoxon and Yoxon (2014), who generally detected seasonality in spraint abundance, but also no correlation between old spraints and otter numbers. However, in a Hungarian stream habitat, a significant correlation between the number of otter scats (including both, old and fresh scats) and the number of individual otters were found, whereby, the correlation coefficient was much higher using fresh scats only (Lanszki et al. 2008). In a pond area in Germany, no significant relationship between fresh scats and otter densities based on capture-mark-recapture estimates was found (Lampa et al. 2015b). Again, this may be due to different social structure and marking behaviour in pond areas, where home ranges and territories are not linear.

For another otter species, Lontra felina, again a strong positive relationship between the number of fresh scats and the number of otter individuals revealed by genotyping of faeces was found (Biffi and Williams 2017). Similar results were drawn for Lontra canadensis (Mowry et al. 2011): not only the number of otter scats per marking site (fresh and old scats pooled), but also the density of marking sites were good predictors of otter abundance.

Another factor which should be considered when relating otter numbers to scat abundance is the temporal scale-more specifically, the time span since the area under study was repopulated by otters should be taken into account. It is assumed that sprainting activity increases with increasing otter densities, as the pressure for potential food resources and mating partners is rising. Whereas in areas with otter densities clearly below carrying capacity of a habitat, the need for intraspecific communication to defend territories and resources is hardly given and a lower sprainting activity can be expected (Jefferies 1986; Hutchings and White 2000). Hence, sprainting behaviour and activity, and consequently scat abundance, might change over time and space from an otter population still in expansion to an otter population coming closer to carrying capacity. For our study areas, we can assume that the recolonisation was already completed when we started our investigations (Jahrl 1999; Kranz et al. 2001; Kranz and Poledník 2009).

\section{Conclusion}

To summarise, our study only partially supported the suggestion of Jefferies (1986) as well as Mason and MacDonald (1987) that scat abundance can be used as a "fine adjustment tool" for population density assessment in combination to the presence and absence data on otter distribution. In contrast, for salmonid streams, we showed that a relationship between the number of otter scats and individuals can only be applied under certain circumstances and in compliance with specific conditions.
Based on our results the use of otter scat numbers as an index for otter density must be scrutinised critically, especially when an assessment of a river stretch or an area is based on scat counts of few marking points only. A careful approach is also recommended when studies to compare and display population trends were carried out in different seasons or under different conditions. Concerning management implications, we suggest to use fresh scats only for assessing relative population densities and population trends, whereas old scats can still be used to monitor otter distribution and population expansion.

As we focused on salmonid streams, in future studies more habitats should be included. The presence and amount of fresh scats does not always correlate with otter numbers (see Lampa et al. 2015b), which may be related to different social structures and marking behaviour of otters due to different habitat conditions and resource availability (linear stream habitats vs. areal habitat in a pond area; lower reaches vs. upper reaches of streams). Furthermore, we suggest a combination of field census methods over extensive areas and local studies using noninvasive genetic monitoring methods to broaden the knowledge about social structure and marking behaviour of otters across different habitats.

Acknowledgements We are grateful to Kathrin Heissenberger and Michaela Bodner for field assistance. For helping with graphical design, we thank Christian Bartl. Sample collection and genetic analyses were carried out within studies funded by the Fisheries Association of Lower Austria and its Regional Fishing Associations (I-V).

Funding Information Open access funding provided by University of Natural Resources and Life Sciences Vienna (BOKU).

Open Access This article is licensed under a Creative Commons Attribution 4.0 International License, which permits use, sharing, adaptation, distribution and reproduction in any medium or format, as long as you give appropriate credit to the original author(s) and the source, provide a link to the Creative Commons licence, and indicate if changes were made. The images or other third party material in this article are included in the article's Creative Commons licence, unless indicated otherwise in a credit line to the material. If material is not included in the article's Creative Commons licence and your intended use is not permitted by statutory regulation or exceeds the permitted use, you will need to obtain permission directly from the copyright holder. To view a copy of this licence, visit http://creativecommons.org/licenses/by/4.0/.

\section{References}

Almeida D, Barrientos R, Merino-Aguirre R, Angeler DG (2012) The role of prey abundance and flow regulation in the marking behaviour of Eurasian otters in a Mediterranean catchment. Anim Behav 84: 1475-1482

Bartón K (2018) MuMIn: Multi-Model Inference. R package version 1.42.1. https://CRAN.R-project.org/package=MuMIn. Accessed 04 June 2019 
Bates D, Mächler M, Bolker BM, Walker SC (2015) Fitting linear mixedeffects models using lme4. J Stat Softw 67:1-48

Beja-Pereira A, Oliveira R, Alves PC et al (2009) Advancing ecological understandings through technological transformations in noninvasive genetics. Mol Ecol Resour 9:1279-1301

Biffi D, Williams DA (2017) Use of non-invasive techniques to determine population size of the marine otter in two regions of Peru. Mamm Biol 84:12-19

Bonesi L, Hale M, Macdonald DW (2013) Lessons from the use of noninvasive genetic sampling as a way to estimate Eurasian otter population size and sex ratio. Acta Theriol 58:157-168

Burnham KP, Anderson DR (2002) Model selection and multimodel inference. A Practical Information-Theoretic Approach. Springer, New York

Burnham KP, Anderson DR, Huyvaert KP (2011) AIC model selection and multimodel inference in behavioral ecology: some background, observations, and comparisons. Behav Ecol Sociobiol 65:23-35

Chapron G, Kaczensky P, Linnell JDC, von Arx M, Huber D, Andrén H, López-Bao JV, Adamec M, Álvares F, Anders O, Balčiauskas L, Balys V, Bedő P, Bego F, Blanco JC, Breitenmoser U, Brøseth H, Bufka L, Bunikyte R, Ciucci P, Dutsov A, Engleder T, Fuxjäger C, Groff C, Holmala K, Hoxha B, Iliopoulos Y, Ionescu O, Jeremić J, Jerina K, Kluth G, Knauer F, Kojola I, Kos I, Krofel M, Kubala J, Kunovac S, Kusak J, Kutal M, Liberg O, Majić A, Männil P, Manz R, Marboutin E, Marucco F, Melovski D, Mersini K, Mertzanis Y, Mysłajek RW, Nowak S, Odden J, Ozolins J, Palomero G, Paunović M, Persson J, Potočnik H, Quenette PY, Rauer G, Reinhardt I, Rigg R, Ryser A, Salvatori V, Skrbinšek T, Stojanov A, Swenson JE, Szemethy L, Trajçe A, Tsingarska-Sedefcheva E, Váňa M, Veeroja R, Wabakken P, Wölfl M, Wölfl S, Zimmermann F, Zlatanova D, Boitani L (2014) Recovery of large carnivores in Europe's modern human-dominated landscapes. Science 346:1517-1519

Dallas JF, Piertney SB (1998) Primer notes: microsatellite primers for the Eurasian otter. Mol Ecol 7:1247-1263

Day CC, Westover MD, Hall LK et al (2016) Comparing direct and indirect methods to estimate detection rates and site use of a cryptic semi-aquatic carnivore. Ecol Indic 66:230-234

Gallant D, Vasseur L, Berube CH (2007) Unveiling the limitations of scat surveys to monitor social species: a case study on river otters. J Wildl Manag 71:258-265

Green J, Green R, Jefferies DJ (1984) A radio-tracking survey of otters Lutra lutra on a Perthshire river system. Lutra 27:85-145

Grueber CE, Nakagawa S, Laws RJ, Jamieson IG (2011) Multimodel inference in ecology and evolution: challenges and solutions. J Evol Biol 24:699-711

Guter A, Dolev A, Saltz D, Kronfeld-Schor N (2008) Using videotaping to validate the use of spraints as an index of Eurasian otter (Lutra lutra) activity. Ecol Indic 8:462-465

Hájková P, Zemanová B, Bryja J et al (2006) Factors affecting success of PCR amplification of microsatellite loci from otter faeces. Mol Ecol Notes 6:559-562

Hájková P, Zemanová B, Roche K, Hájek B (2009) An evaluation of field and noninvasive genetic methods for estimating Eurasian otter population size. Conserv Genet 10:1667-1681

Hurvich CM, Tsai C-L (1989) Regression and time series model selection in small samples. Biometrika 76:297-307

Hutchings MR, White PCL (2000) Mustelid scent-marking in managed ecosystems: implications for population management. Mammal Rev 30:157-169

Illies J (1961) Versuch einer allgemeinen biozönotischen Gliederung der Fließgewässer. Int Rev der gesamten Hydrobiol und Hydrogr 46: 205-213

Jahrl J (1999) Verbreitung des Eurasischen Fischotters (Lutra lutra) in Österreich 1990-1998 (Mammalia). Joannea Zoo 1:5-12
Janssens X, Fontaine MC, Michaux JR et al (2008) Genetic pattern of the recent recovery of European otters in southern France. Ecography 31:176-186

Jefferies DJ (1986) The value of otter Lutra lutra surveying using spraints: an analysis of its successes and problems in Britain. Otters, J Otter Trust 1:25-32

Jones AG, Small CM, Paczolt KA, Ratterman NL (2010) A practical guide to methods of parentage analysis. Mol Ecol Resour 10:6-30

Kalinowski ST, Wagner AP, Taper ML (2006) ML-RELATE: a computer program for maximum likelihood estimation of relatedness and relationship. Mol Ecol Notes 6:576-579

Kalz B, Jewgenow K, Fickel J (2006) Structure of an otter (Lutra lutra) population in Germany - results of DNA and hormone analyses from faecal samples. Mamm Biol 71:321-335

Kean EF, Müller CT, Chadwick EA (2011) Otter scent signals age, sex and reproductive status. Chem Senses 36:555-564

Kean EF, Chadwick EA, Müller CT (2015) Scent signals individual identity and country of origin in otters. Mamm Biol 80:99-105

Klenke RA, Henle K, Kranz A, Ring I (2013) Human - wildlife conflicts in Europe. Springer, Berlin, Heidelberg

Kofler H, Lampa S, Ludwig T (2018) Fischotterverbreitung und Populationsgrößen in Niederösterreich 2018. Endbericht im Auftrag der Abteilung Naturschutz des Amtes der Niederösterreichischen Landesregierung, Final Project Report. http://www.noe.gv.at/noe/Naturschutz/Fischotter_NOe_2018_fin. pdf. Accessed 24 Nov 2019

Kranz A, Poledník L (2009) Fischotter - Verbreitung und Erhaltungszustand 2008 in Niederösterreich. Endbericht im Auftrag der Abteilung Naturschutz des Amtes der Niederösterreichischen Landesregierung, Final Project Report

Kranz A, Poledník L, Pinter V, Parz-Gollner R (2001) Distribution, status and conservation of otters in Lower Austria. Wiss Mitt Niederösterr Landesmuseum 14:39-50

Kruuk H (1992) Scent marking by otters (Lutra lutra): signaling the use of resources. Behav Ecol 3:133-140

Kruuk H (2006) Otters: ecology, behaviour and conservation. Oxford University Press, Oxford

Kruuk H, Conroy JWH (1987) Surveying otter Lutra lutra populations: a discussion of problems with spraints. Biol Conserv 41:179-183

Kruuk H, Conroy JWH, Glimmerveen U, Ouwerkerk EJ (1986) The use of spraints to survey populations of otters Lutra lutra. Biol Conserv 35:187-194

Lampa S, Gruber B, Henle K, Hoehn M (2008) An optimisation approach to increase DNA amplification success of otter faeces. Conserv Genet 9:201-210

Lampa S, Henle K, Klenke R et al (2015a) How to overcome genotyping errors in non-invasive genetic mark-recapture population size estimation - a review of available methods illustrated by a case study. J Wildl Manag 77:1490-1511

Lampa S, Mihoub J-B, Gruber B et al (2015b) Non-invasive genetic mark-recapture as a means to study population sizes and marking behaviour of the elusive Eurasian otter (Lutra lutra). PLoS One 10: e0125684

Lanszki J, Hidas A, Szentes K et al (2008) Relative spraint density and genetic structure of otter (Lutra lutra) along the Drava River in Hungary. Mamm Biol 73:40-47

Lerone L, Mengoni C, Carpaneto GM et al (2014) Procedures to genotype problematic non-invasive otter (Lutra lutra) samples. Acta Theriol 59:511-520

Macdonald SM, Mason CF (1987) Seasonal marking in an otter population. Acta Theriol 32:449-462

Martin EA, Heurich M, Müller J, Bufka L, Bubliy O, Fickel J (2017) Genetic variability and size estimates of the Eurasian otter (Lutra lutra) population in the Bohemian Forest Ecosystem. Mamm Biol $86: 42-47$ 
Marucco F, Boitani L, Pletscher DH, Schwartz MK (2011) Bridging the gaps between non-invasive genetic sampling and population parameter estimation. Eur J Wildl Res 57:1-13

Mason CF, MacDonald SM (1986) Otters: ecology and conservation. Cambridge University Press, Cambridge

Mason CF, Macdonald SM (1987) The use of spraints for surveying otter Lutra lutra populations: an evaluation. Biol Conserv 41:167-177

Miller CR, Joyce P, Waits LP (2005) A new method for estimating the size of small populations from genetic mark-recapture data. Mol Ecol 14:1991-2005

Mowry RA, Gompper ME, Beringer J, Eggert LS (2011) River otter population size estimation using noninvasive latrine surveys. J Wildl Manag 75:1625-1636

Nakagawa S, Schielzeth H (2013) A general and simple method for obtaining $\mathrm{R}^{2}$ from generalized linear mixed-effects models. Methods Ecol Evol 4:133-142

Nsubuga AM, Robbins MM, Roeder AD et al (2004) Factors affecting the amount of genomic DNA extracted from ape faeces and the identification of an improved sample storage method. Mol Ecol 13:2089-2094

Ottino P, Giller P (2004) Distribution, density, diet and habitat use of the otter in relation to land use in the Araglin Valley, southern Ireland. Biol Environ Proc R Irish Acad 104B:1-17

Peakall R, Smouse PE (2006) Genalex 6: genetic analysis in excel. Population genetic software for teaching and research. Mol Ecol Notes 6:288-295

Peakall R, Smouse PE (2012) Genalex 6.5: genetic analysis in excel. Population genetic software for teaching and research - an update. Bioinformatics 28:2537-2539

Pennell MW, Stansbury CR, Waits LP, Miller CR (2013) Capwire: a R package for estimating population census size from non-invasive genetic sampling. Mol Ecol Resour 13:154-157

R Core Team (2018) R: A language and environment for statistical computing. R Foundation for Statistical Computing, Vienna, Austria. URL https://www.R-project.org/. 04 June 2019

Reid N, Lundy MG, Hayden B et al (2013) Detecting detectability: identifying and correcting bias in binary wildlife surveys demonstrates their potential impact on conservation assessments. Eur J Wildl Res 59:869-879

Remonti L, Balestrieri A, Smiroldo G, Prigioni C (2011) Scent marking of key food sources in the Eurasian otter. Ann Zool Fenn 48:287294

Reuther C, Dolch D, Green R et al (2000) Surveying and monitoring distribution and population trends of the Eurasian otter (Lutra lutra). Habitat Arbeitsberichte der Aktion Fischotterschutz e. V., Hankensbüttel

Ripple WJ, Estes JA, Beschta RL et al (2014) Status and ecological effects of the world's largest carnivores. Science 343:1241484

Rivera NA, Totoni S, Monick K et al (2019) A comparison of three methods to evaluate otter latrine activity. Wildl Soc Bull 43:198-207

Romanowski J, Brzeziński M, Zmihorski M (2013) Habitat correlates of the Eurasian otter Lutra lutra recolonizing Central Poland. Acta Theriol 58:149-155

Roos A, Loy A, de Silva P, Hajkova P, Zemanová B (2015) Lutra lutra. The IUCN red list of threatended species 2015: e.T12419A21935287. https://doi.org/10.2305/IUCN.UK.2015-2. RLTS.T12419A21935287.en. Accesed 07 may 2019
Ruiz-Olmo J, Saavedra D, Jiménez J (2001) Testing the surveys and visual and track censuses of Eurasian otters (Lutra lutra). J Zool 253:359-369

Ruiz-Olmo J, Batet A, Mañas F, Martínez-Vidal R (2011) Factors affecting otter (Lutra lutra) abundance and breeding success in freshwater habitats of the northeastern Iberian Peninsula. Eur J Wildl Res 57: $827-842$

Sackl P, Bauer K (2001) Fischotter Lutra lutra (Linnaeus, 1758). In: Spitzenberger F (ed) Die Säugetierfauna Österreichs, Grüne Reihe des, vol Band 13. Bundesministeriums für Land- und Forstwirtschaft, Umwelt und Wasserwirtschaft, Wien, pp 654-664

Schwartz MK, Luikart G, Waples RS (2007) Genetic monitoring as a promising tool for conservation and management. Trends Ecol Evol 22:25-33

Sittenthaler M, Bayerl H, Unfer G et al (2015) Impact of fish stocking on Eurasian otter (Lutra lutra) densities: a case study on two salmonid streams. Mamm Biol 80:106-113

Strachan R, Jefferies DJ (1996) Otter survey of England (1991-1994). A report on the decline and recovery of the otter in England and on its distribution, status and conservation in 1991-1994. The Vincent Wildlife Trust, London

Symonds MRE, Moussalli A (2011) A brief guide to model selection, multimodel inference and model averaging in behavioural ecology using Akaike's information criterion. Behav Ecol Sociobiol 65:1321

Taberlet P, Luikart G (1999) Non-invasive genetic sampling and individual identification. Biol J Linn Soc 68:41-55

Taberlet P, Griffin S, Goossens B et al (1996) Reliable genotyping of samples with very low DNA quantities using PCR. Nucleic Acids Res 24:3189-3194

Vergara M, Ruiz-González A, López de Luzuriaga J, Gomez-Moliner B (2014) Individual identification and distribution assessment of otters (Lutra lutra) through non-invasive genetic sampling: recovery of an endangered species in the Basque Country (northern Spain). Mamm Biol 79:259-267

Waits LP, Luikart G, Taberlet P (2001) Estimating the probability of identity among genotypes in natural populations: cautions and guidelines. Mol Ecol 10:249-256

Weinberger I, Muff S, de Jongh A, Kranz A, Bontadina F (2016) Flexible habitat selection paves the way for a recovery of otter populations in the European Alps. Biol Conserv 199:88-95

White PCL, McClean CJ, Woodroffe GL (2003) Factors affecting the success of an otter (Lutra lutra) reinforcement programme, as identified by post-translocation monitoring. Biol Conserv 112:363-371

Wilson GJ, Delahay RJ (2001) A review of methods to estimate the abundance of terrestrial carnivores using field signs and observation. Wildl Res 28:151-164

Yoxon P, Yoxon K (2014) Estimating otter numbers using spraints: is it possible? J Mar Biol 2014:430683

Zuur AF, Ieno EN, Elphick CS (2010) A protocol for data exploration to avoid common statistical problems. Methods Ecol Evol 1:3-14

Publisher's note Springer Nature remains neutral with regard to jurisdictional claims in published maps and institutional affiliations. 